\title{
Enhancing Cultural Identity Through Speaking Class Using Mind Mapping Board to Face Industrial Revolution 4.0
}

\author{
Olyvia Revalita Candraloka* \\ English Education Department \\ Universitas Islam Nahdlatul Ulama Jepara \\ Jepara, Indonesia \\ olyviarevalita@unisnu.ac.id
}

\author{
Aliva Rosdiana \\ English Education Department \\ Universitas Islam Nahdlatul Ulama Jepara \\ Jepara, Indonesia \\ alivarosdiana@unisnu.ac.id
}

\begin{abstract}
Kudus is identified as Kota Santri due to its identity through its Islamic culture. Cultural awareness must be possessed people surroundings. Teachers can foster it in the classroom activity by approaching students' background knowledge as target culture. Speaking is one way to activate students' ideas, particularly in revealing the culture of Kudus. The qualitative study is used to analyze the integration of cultural identity work and classroom learning at MTS N 2 Kudus. It has a purpose to deliver understanding of students' experience through speaking. MMB is used as a media to ease students to deliver their ideas into speaking. Every concept and idea in MMB is organized into framework of mapping. Hence, students enhance their cultural identity by exploring physical appearance, cultural activities, and their creativity into activities in their everyday lives. Furthermore, cultural identities depict them into sense of belonging also plays a central role in connecting person to social change and act them to study the relationship between the social and the self. By physical appearance, students have identities and self of belonging in society. Thus, it allows mutual influence between self and society. Finally, MMB media is an effective way for students to organize concepts and ideas to support their speaking skills and prepare communication skills in the era of industrial revolution 4.0.
\end{abstract}

Keywords-Mind Mapping Board, speaking, cultural identity, industrial revolution 4.0

\section{INTRODUCTION}

Culture is one factor that shapes identity of particular people in particular community. Kudus is a city with a very close religious culture and religious character of its people making this city nicknamed "Kota Santri". This culture shapes the identity of the religious community with their religious appearance, and through activities and creativities as well. The identity shows a form of belonging towards a culture, called cultural identity. It can be considered as owning the culture and its various boundaries of ethnicity, nationality, language, religion, and gender. Owning the culture means the person embraces all the traditions that have been passed down through, such as the clothed appearance, cultural activities, and creativities realized through art. Cultural identities based on physical conditions are divided into two individual identities and collective identities (2004).

People should have the sense of belonging of their culture as their identities. Students are the right target to introduce cultural identity through speaking activities in the classroom. Introducing identity to students is important to give their awareness of its origin. The identities support individual nature and nurtures which include experiences, talents, skills, beliefs, value, knowledge, that all of these represent who they are, what their status in their family, work, social, environment, country, and beyond the globalization revolution industry era 4.0 (2015). Ideas development toward cultural identity needs specification in description orderly for students in speaking.

Ideas play an important role in negotiating communication. Speaking skill is one productive activities skill and important skill to be carried out in a conversation. It supports students to be able to communicate and be able to develop creative ideas. Besides, it is an interactive process for constructing and receiving information. This skill is very important. Therefore, speaking skills must be trained as possible in learning process of classroom. In the 2013 formal education curriculum, English was taught at the earliest level at the junior high school. Therefore, this research was conducted on junior high school students. Practically, students' speaking skills are still relatively low.

Communication skills play an important role in supporting the 4.0 industrial revolution. It impacts individuals and societies. Industrial 4.0 has huge potential to develop and fundamentally change how society operates by providing entirely novel solution to existing problems in society. The innovation exists to answer the problems by social innovation in the context of industry 4.0 by new technological innovation in the form of artificial intelligence, robotics, drones, virtual reality, and IoT (Internet of Things) (2017). Furthermore, cultural identities depict them into a sense of belonging is also plays a central role in connecting person to social change and act them to study the relationship between the social and the self. 
Junior high school students characteristically are a transition period from young learners to adolescent required visual and creative learning (2003). One of the visual and creative learning is learning media. The learning media able to aid students in developing ideas is mind mapping board (MMB). It is the strategy for assisting students order and structures their thinking through mentally mapping words or notions. The MMB contains visual frameworks like figures, diagrams, or charts utilized to display structural knowledge. It is influential in assisting students communicate information because they can explain complex notions in simple, meaningful representations so that learners can expand a comprehensive comprehension of the content to be learned. A mind map is a graphic organizer in which the major classes are described as chapters of larger chapters (2004). By mind mapping, students enhance their selfbelonging to cultural identity through speaking class for students at MTS N 2 Kudus.

A school is a place of a school culture teaching area in language classes. Learning to teach culture means developing an identity as a culture teacher by critically stimulates students' own cultural and biographical root (1997). It is suggested that in examining abstract construct of culture and identity, collaborative inquiry and self-reflection of participants, including researchers and students, are very valuable. In the line of this research, other research has further revealed that language teachers' cultural identities interacted with various aspects of their teaching, such as the material selection, and teaching approaches, in significant ways (1997), (2011), (2008). The important link between teaching practices and enhancing students' self-belonging to cultural identity through speaking class pointed to the value of teachers doing cultural identity work within their educational context.

The implications of this prior to work are that a) language teacher education needs to pay more attention to take the speaking topic material of physical appearance to enhance students' cultural identities and self of belonging of society. Thus, it allows mutual influence between self and society. Finally, MMB media is an effective way for students to organize concepts and ideas to support their speaking skills and prepare communication skills in the era of industrial revolution 4.0 $(2016,2018,2017)$. Enhancing cultural identity through speaking class using mind mapping board to face industrial revolution 4.0 is one strategy to prepare students to have self-belonging toward their own identities and their readiness to enter the impact of 4.0 era as well.

\section{REVIEW OF LITERATURE}

\section{A. Cultural Identities and Learner Identities}

Identity formation becomes a social process that occurs concerning various reference groups. Identity is an individual subjective process in which individuals make decisions and choices about their own identity according to both personal and social influences within a particular context (1998). However, the interpersonal aspects of identity formation suggest that it is not only how the individual understands and identifies with the group that shapes identity but also how the groups treat the individuals, creating an interactive constructed identity development process $(1998,2003)$. The social aspect of identity development itself has been reflected in racial/ethnic identity (R/EID) models through the concept of belonging and social (1990). The belonging addresses the recognition and acceptance of a member by other members in a group. This sense of belonging, thus, to a particular group provides a community that fosters one's identity, feelings of acceptance, and validation of one's identity (1996).

It has been drawing attention from the researchers since the 1970s and 1980s the relationship between identity and language (2006) The distinction between social identity and cultural identity which were seen each of them as the relationship between the individual and the larger social as mediated through institutions such as families, schools, workplaces, and the relationship between an individual and members of particular ethnic group who are considered to share a common history, a common language and similar ways of understanding the world; respectively Norton finds the diverse research findings problematic (2006). However, this distinction is vaguer since the concept of socio cultural identity intertwined the similarities belonging to both concepts. It is a dynamic construct changing across time and space constantly; therefore it is complex and multifaceted. It constructs and is constructed by language. It is affected by and social processes and classroom practice, as well.

In the classroom practice, students are asked to describe their cultural identities through physical appearance, activities, and creativities. These depict them into sense of belonging is also plays a central role in connecting person to social change and act them to study the relationship between the social and the self. By physical appearance, students have identities and self of belonging in society. Thus, it allows mutual influence between self and society through speaking class. This speaking skill supports students to be able to communicate and be able to develop creative ideas. Thus, communication skills play an important role in supporting the 4.0 industrial revolution.

\section{B. The Effect of Industrial Revolution Era 4.0 in Enhancing Cultural Identity Through Speaking Class}

The world has been entering the industrial revolution 4.0, or it is also called The 4th Industrial Revolution Era in which all human activities are changed by technology. All activities carried out become unlimited computing and unlimited data due to the influence of internet and digital technology as the backbone of movement and human connectivity and machine as well (2018). This is included in the world of education, era 4.0 as well as disrupting human activities, especially in the fields of science and technology and higher education. There is something different from the current 4.0 industrial era which is disruptive and anti-mainstream compared to the previous era (2017). The most important thing is, according to Mubarak, is literacy (2018). Students are expected not only able to read, write, and count but also literacy for data information, technology, and people. In this case, education must be able to the industrial condition of the 4.0 era that is needed for today's society especially preparing competencies early. One of them is verbal competence communication (2016). 
Speaking skill is the ability to speak in English that must be mastered by students creatively expressing their ideas through communicative approach (2015). However, not all students can express their ideas systematically and precisely. The cause of students experiencing difficulties and low learning outcomes in speaking is the teacher is the class has limited teaching strategy and is less innovative (1996). By mind mapping, every concept and idea are organized into framework of mapping.

\section{Mind Mapping Board}

All concepts, ideas, as well as organizing presented in a framework of mapping is called a mind map. Mind mapping technique is considered a suitable technique and also as a media in a learning process for students to develop their ideas by putting keywords in provided spaces. The process of learning is using pictures, alphabets, symbols, and colors, which is interesting for students. Besides, it motivates them to store information in branched nerve cell boxes like a branch of all centered on one main word as the main idea (2007). Besides, mind mapping eases students to develop their ideas starting from main idea and then breaking it down in detail. Mind mapping model as a strategy in teaching will ease students to lay ideas out and to express ideas in communication through speaking (2017). There are several steps in conveying ideas. The first thing to do is to convey main idea as a central idea, which is then developed into themes derivatives with branches a link between the main theme and the theme derivative. Then, the second step is to box the ideas into mind mapping boxes visually used to memorize and to stimulate. This activity would be more efficient than traditional notes, which tend to be less creative as a teaching media. A learning media is one important aspect in classroom learning.

In the teaching-learning process, learning media stimulates attention, thoughts, feelings and student skills in the process of implementing learning. There are several types of instructional media including visual media (graphics, diagrams, charts, comics, and posters), audio media (radio, tape recorders, language laboratories, and the like), projected still media (slide, OHP), and projected motion media (film,television, video, computer). The use of audiovisual application media in a speaking class gives good contribution to the academic world $(2014,2010)$. The use of speaking learning media to Senior High School students shows that the learning application using audiovisual media helped them to speak correctly and accurately emphasized on the message English (2011). Game Media can help students to increase their speaking skills to overcome their less motivation of learning and develop the method to overcome the problem of English learning $(2017,2012)$. The use of audiovisual application media in speaking class makes a good contribution in Academic World. The result showed that this application helped students to speak correctly and accurately with an emphasis on communication messages. Likewise, the media of Song Base Learning for grade 1 of Junior High School SinjaiBorong has its development especially in listening and speaking skills (2012).

Besides, implementing mind mapping as a complement to the learning strategy can also increase speaking activities in classroom so greatly recommended for teachers to make speaking learning activities creative, innovative, and interesting $(2013,2017)$. The result showed that the use of mind maps could influence students' speaking skills optimally. The implementation of mind mapping strategy can stimulate students to think critically including inductive thinking, analysis, and reflect on learning (2017). The use of the board will help students to explore their ideas that students have their critical thinking about something around them. A combination of mind mapping and learning strategies will complete the teaching-learning process. In the previous study, the strategy of group guidance was used along with the solution steps of using mind maps, and self-reward provided an effective result to increase students learning skill (2013). Mind mapping illustrates visual on the board. Teaching using blackboard media is often written for an idea to encourage students to develop their ideas through mind mapping. Mind mapping is used to facilitate students exploring their ideas and learning. In other words, it eased students to apply their language skills (2010). By mind mapping, researchers enhance students' cultural identity by exploring physical appearance, cultural activities, and their creativity into activities in their everyday lives.

\section{METHOD}

The method used is a qualitative approach. The data collections are students' descriptions of their cultural identity and how they influence them through their English speaking skills. After data was collected, analyzing data was conducted to distinguish the elements that constructed students' cultural identity and the influence of speaking skills. This study approach was inductive, starting from the students' responses and not trying to influence them. The topic of speaking class is describing physical appearance, cultural activities, and their creativity into activities in their everyday lives, using MMB as media to ease them to speak. Besides, Communication skills play an important role in supporting the 4.0 industrial revolution. It becomes an effective way for students to organize concepts and ideas to support their speaking skills and prepare communication skills in the era of industrial revolution 4.0. By physical appearance as a topic of speaking class, students have identities and self of belonging in society. Thus, it allows mutual influence between self and society. In this case, classroom observation was a research object to analyze the integration of cultural identity work and classroom learning at MTS N 2 Kudus.

Recent studies have been conducted quantitatively on the topic of identity-based on the qualitative data, even though there have been some quantitative experiments as well concerning the use of a quantitative questionnaire. In this case, the data collected do not give a detailed account of identity but remains at the surface (2014). A qualitative approach, thus, is the best option for the identity research experience. 


\section{FINDING AND DISCUSSION}

There are three distinct categories of describing physical appearance, cultural activities, and their creativities into activities in their everyday lives as a central topic in speaking class: the students' origins and their identity, factors shaped from cultural identity, and the competencies developed.

\section{The students' origins and their identity}

Most students in their speaking class stated their cultural identity is Javanese, connected to their family, traditions, and customs. By the country they live in, they say Indonesian. They were describing their selves by the physical appearance of Javanese characteristics as being the formative element that defined their cultural identity. Here are some of their descriptions in the speaking class: "I am Javanese, and I am proud of it. I am an Indonesian too, and I am proud of it too. My father is Javanese. He has short black hair, dark complexion, mustache and beard. He is always wearing kopiahand sarong at home. My mother is wearing veil. We are Moslems. People around my house are mostly Moslems. But they are also nonMoslems. We are Indonesians. And we are Javanese. No matter how different we are but we are Javanese." The general attitude performed from speaking in one of pride when identifying with their parents' heritage.

Besides mentioning Javanese as origins, the traditions and customs they have as an identity of their culture mentioned in speaking class. "I am very proud of living in Kudus. This city has many traditions such as dandangan, kupatan, and bukakluwur." This feeling represents pride to Kudus acknowledges their identity as Javanese who lives in Kudus.

\section{Factors shaped by cultural identity}

The most important factor influencing the students' cultural identities mentioned in students' speaking class is the Javanese language, which proves to be great importance. The element mentioned as characteristics of physical appearance is also local language used, which is Javanese with Kudus dialect. They use this dialect through interaction with other people, ceremonial, and learning about the target culture leads to awareness of cultural practices both in individualistic and collectivist societies. However, the most significant element would be knowledge of Javanese as one culture to be maintained. One says in a speaking class: "Javanese is my language when I speak to dad and mom and all people surrounding me."

\section{Competence developed}

English competence is developed through speaking class. The topic of cultural identity used in the speaking class is also a competence used to develop intercultural competence. Discussing its importance, the manner can be developed, and also its assessment, by all of these, students also mentioned the fact that they have learned about cultural identity specifically physical appearance through speaking class using MMB to help them elaborate ideas to explain the specific components of culture they mentioned (2004). In other words, elaborating characteristic of cultural identity of Kudus brought them cultural awareness of their own culture. "I study English through speaking about culture of Kudus has made me more aware of my own culture as my identity that I'm Javanese who are living in Kudus." Then by cultural awareness toward their culture, it also developed them to the awareness of multicultural identities in Indonesia even the world. It was proved from their speaking about tolerance, "Kudus has a tradition of dandangan in which no other cities has dandangan like in Kudus." The connection between language and cultural identity contributes to the process of identity development through speaking class with MMB to ease students elaborate their ideas of explaining self-identity by their physical appearance and their culture.

The three categorizations are implemented through speaking in the classroom using Mind Mapping Board (MMB) to ease them making outline and elaborate them to use into speaking. The topic determined is talking about Cultural Identity in Kudus. The three ideas are taken to represent cultural identity in Kudus, they are physical appearance, cultural activities, and habits. The detail information to convey dealing with ideas is as follows:

\section{a) Physical appearance}

The detail information described is black hair, wearing kopiah for men, and wearing veil for women. Those are commonly appearance of people in Kudus describing the society.

\section{b) Cultural activities}

It is dealing with ceremonial conducted in Kudus such as kupatan, dandangan, and BulakLuwur. Dandangan is a festival to welcome the holy month of Ramadan. Then, after Ramadan, usually people at Kudus celebrate Kupatan as gratitude after Muslims fasted for a month. In other side, there is a tradition which is only Kudus people celebrate it in every 10 muharram, namely BukakLuwur. The people gather in the Kudus tower to witness the changing of tomb valance of Sunan Kudus.

\section{c) Habits}

People of Kudus verbally talk with each other using Javanese with Kudus dialect. Due to the religious community, most people have the habit of tahliland reading Al-Qur'an.

The three things mentioned above represents cultural identities of people in Kudus with their own characteristics which can be different with other communities. By describing the characteristics of people in Kudus, students as a part of society feel a self-belonging instilled. They will also aware to preserve their culture for generations. It is their duty to introduce their culture to the world using technology of internet into speaking. Mind mapping board is a solution to ease students to speak by elaborating every word that describing cultural identity of Kudus. 


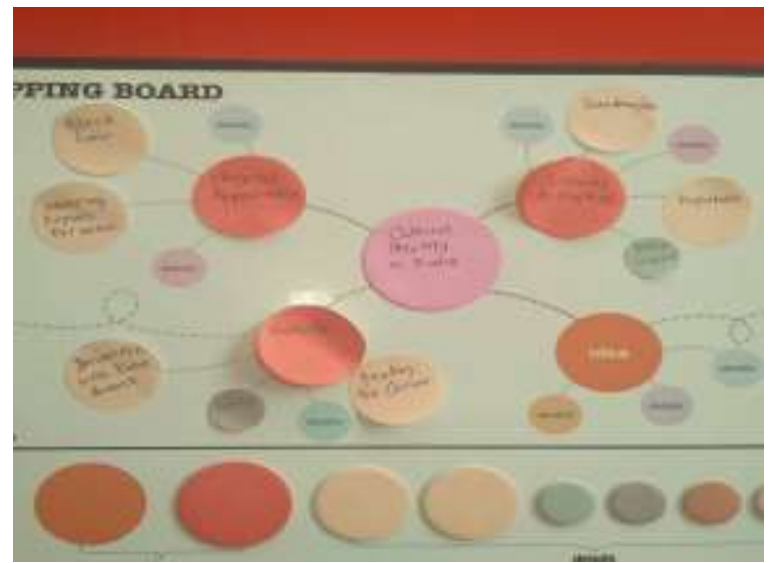

Fig. 1.Describing cultural identity using Mind Mapping Board.

There are three strategies used underlying developmental in strategy discovery and strategy change, and they are by encoding locations within each space, noticing a potential analogy between spaces, and detecting precise mapping correspondences. Students presented with one topic as a word designed to evoke thought about the physical appearance of his families such as the color of hair, the costume, and the habit. They were asked to describe three that they would need. By this exploration using MMB media, it is known that mind mapping increases creativity of students and allows cognition to the topic, which is about cultural identity so that they have self-belonging to their identity by describing it correctly through speaking.

\section{CONCLUSIONS}

Enhancing cultural identity is meant to increase cultural awareness of students toward their identities by expressing it through speaking especially for students. Moreover, in this revolution industry era 4.0, cultural identity must be considered and preserved for generations in order to be sustainable. The identities developed automatically support human's nature and nurture represents who they are, what their status in family, work, social, environment, country, and even beyond globalization revolution industry era 4.0; particularly Kudus as a city identity. City identity is the pride that will be embedded in the heart of every citizen. Citizens born there, also live in it.

In the $4^{\text {th }}$ era, people are required to have the ability to communicate in various media about their cultural identity so it is known to the wider community. Therefore, it is necessary to prepare students' communication skills early in the speaking class. By speaking, students' ideas are explored through three topics about physical appearance, cultural activities, and their creativity in activities in their everyday lives. By the topic of cultural identity, students have their sense of belonging and a central role in connecting person to social change and, then, act them to study the relationship between the social and the self. By physical appearance, students have identities and self of belonging in society. Thus, it allows mutual influence between self and society. Besides, enhancing cultural identity also is meant to develop intercultural competence. There are three distinct categories of describing physical appearance, cultural activities, and their creativities into activities in their everyday lives as a central topic in speaking class: the students' origins and their identity, factors shaped from cultural identity, and the competencies developed. MMB is used to ease them to speak coherently.

\section{REFERENCES}

Jenkins, Richard. (2004). Social Identity. London and New York. Routledge. Altugan, A. S. (2015). The relationship between cultural identity and learning. Procedia-Social and Behavioral Sciences, 186, 1159-1162.

Morrar, R., Arman, H., \& Mousa, S. (2017). The fourth industrial revolution (Industry 4.0): A social innovation perspective. Technology Innovation Management Review, 7(11), 12-20.

Harmer, J. 2003.The Practice of English Language Teaching, 3rd Ed, New York: Pearson Education Limited.

Budd, J.W. (2004). Employment with a Human Face: Balancing Efficiency, Equity, and Voice. Ithaca, NY: ILR Press.

Duff, P.A. \& Uchida, Y. (1997).The Negotiation of Teachers' Sociocultural Identities and Practice in Postsecondary EFL Classrooms. TESOL Quarterly, 31(3).

Fichtner, F., \& Chapman, K. (2011).The cultural identities of foreign language teachers.L2 Journal, 2.1, 116-140.

Menard-Warwick, J. (2008). The cultural and intercultural identities of transnational English teachers: Two case studies from the Americans. TESOL Quarterly, 42.4, 617-640.

Hecklau, F., Galeitzke, M., Flachs, S., \& Kohl, H. (2016). Holistic approach for human resource management in Industry 4.0. Procedia CIRP, 54, 1-6. Available online at https://ac.els-cdn.com/S2212827116308629/1-s2.0S2212827116308629-main.pdf? tid=7811f3a1-b332-430c-be33-

4d6a8d2d5218\&acdnat $=1535046789 \quad 575 \mathrm{~b} 38 \mathrm{~d} 981 \mathrm{c} 3717 \mathrm{f} 3 \mathrm{~d} 43 \mathrm{baab} 73 \mathrm{cffdb} 9$. Accessed on 8th August 2018.

Satya, VentiEka. (2018). Strategi Indonesia MenghadapiIndustri 4.0. Info SingkatVol. X, No. 09/I/Puslit/Mei/2018. PusatPenelitianKeahlian DPR RI Gd. Nusantara I Lt. 2: Jakarta.

Sadiyoko, Ali. (2017). Industri 4.0: Ancaman, TantanganatauKesempatan?.OratioDiespada: Dies Natalis XXIV FakultasTeknologiIndustriUniversitasKatolikParahyangan 20 April 2017.

Root, M.P.P.P. (1998). Reconstructing Race, Rethinking Ethnicity.In A. S. Bellack\& M. Hersen (Eds.), Comprehensive clinical psychology (pp.141-160). New York: Pergamon Press.

Suyemoto, K.L.\& Dimas, J.M. (2003). Tobe included in the multicultural discussion: Check one box only. In J. S. Mio \& G. Iwamasa (Eds.), Culturally Diverse Mental Health: The Challenges of Research and Resistance (pp. 55-82). Philadelphia: Brunner-Routledge.

Phinney, J. S. (1990). Ethnic identity in adolescents and adults: Review of research. Psychological Bulletin, 3, 499-514.

Hagerty, B. M., Williams, J.C., Coyne, J.C., \& Early, M.R. (1996).Sense of belonging and indicators of social and psychological functioning.Archives of Psychiatric Nursing, 4, 235-244.

Norton, B. (2006). Identity and Sociocultural Construct in Second Language Research.In K. Cadman \& K. O' Regan (Eds.), TESOL in Context [Special Issue], 22-23

Mubarak, $\mathrm{H}$.

KontribusiUsaidPrioritasdalamMenumbuhkembangkanBudayaLiterasi SekolahSd/Midi KabupatenLangkat. Journal AnalyticaIslamica, 7(1), 47-59.

Fadhilawati, Dian.

(2015).

PeningkatanKeterampilanBerbicaraBahasaInggrisMelaluiPendekatanKomunik atifMahasiswa Program StudiBahasaInggris UNISBA. Lingua, 12(2): 211 -221.

Khan, I. (2013). Speaking skills and teaching strategies: The case of an EFL classroom. Elixir International Journal, 58(10), 14557-14560.

Buzan, T. (2007). Bukupintar mind map untukanak: agar anakjadipintar di sekolah. GramediaPustakaUtama. 
Blessing, OluwatosinOmolaradan Bello Theodora Olufunke.(2015). Comparative Effect of Mastery Learning and Mind Mapping Approaches in Improving Secondary School Students' Learning Outcomes in Physics. 2015; 3(4): 78-84 Published online July 30, 2015 (http://www.sciencepublishinggroup.com/j/sjedu)

Wahyuningsih, Maria Goretti Sri, danHarisMudjiman. (2014). Penerapan Audio Visual DalamPembelajaranBahasaInggris (StudiKasus di SMP N 3 Bawen). JurnalTeknologiPendidikan Dan Pembelajaran. Vol.2, No.1, hal 79 - 92, EdisiMaret 2014.http://jurnal.fkip.uns.ac.id

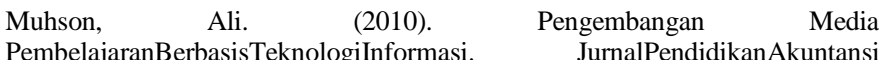

Indonesia, Vol. VIII. No. 2 - Tahun 2010, Hlm. 1 - 10

Untung, Slamet. (2011). Aplikasi Media Audio-Visual DalamPembelajaran Speaking Skill denganPendekatanAudiolingual: StudiKasus di MAN Batang. JurnalPenelitian Vol.8, No.1., Mei 2011, hlm. 91-110.

Nurbadri. (2017). English Games UntukMeningkatkan Speaking Skill Dan MotivasiSiswaKelas X SMK. Jurnal EDUCATION (J.Edu). Volume 3 Nomor 2, 2017, Hlm 68-73.

Hakim, Muhammad Luqman, AkhyardanAsrowi.(2017). Pemanfaatan Media Pembelajaran Game InteraktifDalamPembelajaranKosakataBahasa Arab. Vol. 2 No. 2 | 157-162http://journal.imla.or.id/index.php/arabi.

Muhsin, MuhArief. (2012). Pembelajaran Media Songs Base Learning SiswaKelas VII SMP Negeri 1 SinjaiBorongkabupatenSinjai. Jurnal Media Volume 1 No. 2.Edisi Juni 2012.
Zipp, Genevieve \& Catherine. (2013). Prevalence of mind mapping as a teaching and learning strategy in physical therapy curricula.Journal of the Scholarship of Teaching and Learning, Vol. 13, No. 5, December 2013, pp. 21 - 32.

Mustajib, Agus. (2017). Improving The Students' Speaking Ability By UsingMind Mapping And Guided Questions At Fourth Semester of English Education Study ProgramAt the Islamic University of Indragiri Tembilahan.English Journal of Indragiri (EJI) 2017, Vol. 1, No. 1.

Hamid, GadhaA Abdel. (2017). Mind Maps as a New Teaching Strategy for Medical Students.Volume 3 Issue 3 - 2017. MOJ Anat\&Physiol 3(3): 00090. Diakses di https://www.researchgate.net/publication/315054916. King Abdul Aziz University: Saudi.

Samseno, AkhtiarSigit, EdyPurwanto, danSutarno. (2017). BimbinganKelompokdenganPetaPikirandan Self-Reward UntukMengembangkanKeterampilanBelajarSiswa.

JurnalPsikoedukasidanKonseling.Vol $\quad 1, \quad$ No. $\quad 1, \quad$ Juni 2017.http://jurnal.uns.ac.id/jpk

Wang, Wen-Cheng, Lee, \& Chu.(2010). A Brief Review on Developing Creative Thinking in Young Children by Mind Mapping. International Business Research Vol. 3, No. 3; July 2010. Canadian Center of Science and Education: Canada. www.ccsenet.org/ibr

Rezaieiet, S., Khatib, M., \&Baleghizadeh, S. (2014). Language identity among Iranian English language learners: a nationwide survey. Journal of Multilingual and Multicultural Development, 35(5), 527-536.

Byram, Michael, Feng, Anwei. (2004). Culture and language learning: teaching, research

and 